\title{
Levels of Information Needs as Perceived by Women Culinary Entrepreneurs in Depok Municipality, Indonesia
}

\author{
Mashadi Said \\ Faculty of Communication, University of Pancasila, \\ Srenseng Sawah Jakarta Selatan, Indonesia 12640 \\ Diana Anggraeni \\ Faculty of Communication, University of Pancasila \\ Srenseng Sawah Jakarta Selatan, Indonesia 12640 \\ Diah Febrina \\ Faculty of Communication, University of Pancasila, \\ Srenseng Sawah Jakarta Selatan, Indonesia 12640
}

\begin{abstract}
Culinary business has become a business choice for a high number of women in the area of Depok Municipality, Indonesia. This research is aimed at finding out the levels of information needs of women culinary entrepreneurs in undertaking their business processes based on five categories of the types of information, including product, product development, training, marketing, and finance. Data on the levels of information needs under the five categories of the types of information were obtained from 96 women culinary entrepreneurs through a survey. The result of the research reveals that out of the five categories of the types of information fully needed by women culinary entrepreneurs, the 'product' and 'training' information occupies the highest position, at $86.5 \%$ of the total responses, followed by marketing information $(81.2 \%)$, financial information $(80.2 \%)$, and product development information $(77.1 \%)$. It implies that women culinary entrepreneurs, especially in Depok Municipality, strongly need various types of information related to their culinary business. Therefore, the related agency, particularly the government, need to take strategic measures to provide information required by women culinary entrepreneurs in Depok Municipality in particular and in Indonesia in general.
\end{abstract}

Keywords: Information need, entrepreneur, women culinary entrepreneur

\section{INTRODUCTION}

This research focuses on information needs of women culinary entrepreneurs in Depok Municipality, Indonesia in a culinary business. They were selected since culinary has become a business widely developed by women entrepreneurs in Depok Municipality. Culinary busines categorized as a creative industry within the scope of Micro, Small and Medium Enterprises (MSMEs) has contributed to the revenues of Depok Municipality reaching 65\%. There are currently 1000 MSME business actors dominated by culinary business and fashion business generally run by women.

The result of this research will be very useful for the proponents and institutions related to entrepreneurship to take strategic measures in order to satisfy the information needs of women culinary entrepreneurs in Depok Municipality, in particular and in Indonesia in general. In addition, it will also be very beneficial to the proponents of community 
empowerment, especially women empowerment in Indonesia to help women entrepreneurs identify various types of information required to make right decisions.

A number of previous studies have been conducted to explore the information needs of entrepreneurs. For instance, Yusuf (2012) found that information was needed by entrepreneurs to make right decisions and to reduce uncertainty. An entrepreneur required information to improve his business. From a variety of studies, the information needs related to entrepreneurship were among others conducted by Murari and Nagarkar (2013) who found that when starting a business, most of entrepreneurs required information on consumers' needs, marketing, finance, loan, legal information, and technical information.

Research on the information needs of women entrepreneurs has been long conducted. In his research conducted in 50 women entrepreneurs in Dallas Municipality, Texas, Nelson (1987) examined the types of information they needed as women entrepreneurs. There were 13 needs, including information needs of production techniques, supervisory methods, and personal management. In addition, research conducted by Chaudhary (2015) revealed that women entrepreneurs required managerial and technical information. The needs of technical information were related to the addition of values, the latest technology, raw materials, and others. The managerial information consisted of information on the nearest market to procure raw materials and to sell finished products, information on financial sources, transportation facilities, government schemes, market trends, consumers' preferences, and budgeting. Furthermore, Yohana (2016) found that the information fully needed by entrepreneurs was about making a plan to start a business.

The finding of Chaudhary, op.cit. was strengthened by the study of Kassim, et. al. (2016) which revealed that the most common types of information needed by the managers of Small and Medium Enterprises (SMEs) were information on business opportunities, followed by financial sources, market trends, business locations, surveys, sources of raw materials, products, customer information, government regulations/policies, and competitors. The types of information frequently used to make decisions were information on business/competitor opportunities, followed by finance, analysis methods, markets, data, suppliers (raw materials/products), and technological innovation. In a different study, Kassim (2010) indicated that the other business information needed consisted of courses, business fairs, customer e-mails, business premises, things related to government, and technical training.

Kassim, Buyong, and Kasmarini (2014) found a result which was almost the same with that the previous studies related the most important information needed by entrepreuners, including preparing business plans, services provided by the government, and business opportunities. Other information comprised financial plans by finding the cash flow information, financial assistance, and profit planning. They also required information on license registration, and permit in relation to the process of establishing a business, registration of Employees Provident Fund (EPF) for employers and workers. Finally, the important information required was related to the operation plan, information on qualified suppliers, cheap vendors, and technical services.

The results of the above research showed that the prospective entrepreneurs and the entrepreneurs required various types of information related to entrepreneurship before they started or when they conducted their business. In addition, the results of the previous research revealed that the needs of business information were still generally focused on entrepreneurs, rather than on women culinary entrepreneurs. Therefore, research on information needs particularly for women culinary entrepreneurs are still required. This research focuses on 
identifying information needs related to women culinary entrepreneurs, especially in Depok Municipality, Indonesia.

\section{THEORETICAL FRAMEWORK}

The theory underlying this research is the theory of information needs related to culinary business. It is based on the theory proposed by Nation \& Macalister (2010) which suggests that a need is grounded on three aspects, including necessities (what is required), lacks (what is not known yet, but should be known), and wants (what is desired) and the theory of culinary business needs based on the results of studies from a variety of literatures about culinary business needs, information needs by culinary entrepreneurs which consists of the needs before starting and when running a culinary business, including five categories, such as product, training, marketing, finance, and product development.

\section{Information Needs}

Information needs appear due to several factors. Nicholas \& Herman (2005) suggested that the factor resulting in the emergence of information needs was to meet human needs, including physiological, psychological, and cognitive needs. Yates (1984) proposed four categories to satisfy human needs, consisting of empirical knowledge, personal experience, corporate human experience, search for monotony diversion, physical and mental exhaustion, frustration, confusion, conflict, and failure. In addition, Faibisoff \& Ely (1974) suggested that information needs were a form of activity to solve problems or to make decisions.

\section{Information Needs of Culinary Business}

The information needs of culinary entrepreneurs comprises the needs prior to starting and when running a culinary business. Further, the needs are divided into five categories, including product, training, marketing, finance, and product development.

\section{Product Information}

In general, product is everything which is offered to the market to draw attention, to be purchased, used, or consumed and can satisfy the desires or needs of consumers (Kotler, Armstrong \& Cunningham, 2005). In this research, product information includes preproduction and post-production information. Pre-production information consists of the types of basic materials, availability of raw materials in the market, the nearest market to purchase raw/basic materials, variation of taste, and variation of recipe. Post-production information includes variation of shape, and brand needs. What is meant by product information is everything related to information on the type of raw materials, that is the materials required to be processed into culinary products. The availability of basic materials in the market is the availability of sufficient raw materials to adequately and sustainably produce culinary products. Information on the nearest market to obtain basic materials is the place where the basic materials are sold. In additition, information on the variation of recipe and variation of taste is the basic concept to produce culinary products which is varied and suitable with the customers' tongue.

Other information is post-production information which includes information on the variation of shape and brand needs. Information on the variation of shape is information on the pieces or indent (lekuk) of culinary products (dried and wet cake) that may attract consumers to buy. Brand information is information on the name, symbol, sign, design, or combination of them to be used as an identity of culinary products that can distinguish them from other products. According to Kotler \& Keller (2014), brand image is the customers' perception and belief, as reflected in the association within the consumers' memory. 


\section{Training Information}

In this research, training refers to the definition of training proposed by DeCenzo \& Robin (1999). They defined, "training is a learning experience in that it is a relatively permanent change in individual that will improve the ability to perform on the job". This definition contains the meaning of learning to improve one's ability in undertaking a job or activity. In terms of culinary, the meaning of training is the training in product development, financial management, product promotion, business management, and self-development.

Product development training is an effort to create new products, and to improve or modify old products in order to meet market demands and consumers' tastes (Yamit, 2003). Information on financial management refers to how culinary entrepreneurs allocate or use funds efficiently and wisely. Information on product promotion refers to the efforts to inform or persuade prospective consumers of a product with the purpose of increasing awareness, creating interest, generating sales, or creating a product loyalty (McCarthy, 1964; Rajagopal, (2007). In addition, information on business management intended in this research is how culinary entrepreneurs run a business in a planned and measurable manner (Likert, 1967). The last is information on self-development. It refers to the efforts to help culinary entrepreneurs develop abilities, knowledge and skills related to culinary business.

\section{Marketing Information}

Drucker (1954) suggested that marketing is a very important thing for a business. Kotler, Armstrong \& Cunningham, op. Cit. proposed that marketing is an attempt to satisfy customers' needs and desires. In this research, marketing information includes information on the nearest market to sell culinary products, consumers' interest in the types of product (product trends), availability of transportation for women culinary entrepreneurs to deliver their culinary products to consumers, availability of partners/resellers, and types of transportation to deliver products to consumers.

\section{Financial Information}

Financial information being the focus of this research is everything related to the culinary business finance which includes the selling prices of products in the market, costs of delivering products to consumers, prices of raw/basic materials, prices of other culinary entrepreneurs products, costs of packaging, and fees for obtaining a business permit from the related Ministry. The selling prices of products in the market involve a balance between the purchasing power of consumers and the production costs. Product delivery costs are related to information on the cost consideration that must be spent by woman culinary entrepreneurs to determine the choice of delivery services for culinary products to consumers. The prices of basic materials are related to the amount of funds that must be spent by women culinary entrepreneurs to buy basic materials to determine the quality and quantity of culinary products. In addition, information needs are related to the selling prices of the same products by other culinary entrepreneurs concerning the business of culinary entrepreneurs to determine the selling prices of their culinary products. Packaging costs are related to the amount of funds that must be spent to properly choose the product packaging. Finally, information on the fees for obtaining a business permit is the amount of funds that must be spent by women culinary entrepreneurs to get their culinary business permit.

\section{Product Development}

In general, product development as previously described is an effort to create new products, improve, and modify old products in order to meet market tastes. However, in this section, the focus of this research is information on the composition of materials (nutrition, hygiene, and halal or permitted by Islamic law), regulation (halal by Indonesian Ulema Council), Ministry of 
Health, Ministry of Trade, arrangement of IPR, etc.), brand attractiveness, packaging, display. First, information on the composition of materials is very important for women culinary entrepreneurs in Depok Municipality as the culinary product consumers are generally Moslems who are very sensitive to the halal of culinary products. This is closely related to the halal regulations issued by the Ministry of Religious Affairs, the Ministry of Health, and the Ministry of Trade. In addition, the other important information for women culinary entrepreneurs is information on the arrangement of copyright.

\section{METHODS}

\section{Respondents}

This research employed a quantitative approach through a survey of 96 women culinary entrepreneurs in Depok Municipality, Indonesia as the respondents. They have some characteristics. Firstly, $60.4 \%$ of the respondents are at the age of $40-49$ years, $25 \%$ at the age of $30-39$ years, $7.3 \%$ at the age of $50-59$ years, $5.2 \%$ at the age of $20-29$ years, $7.3 \%$ at the age of 50-59 years, and $2.1 \%$ above the age of 60 years. Secondly, their educational levels are generally varied, consisting of undergraduate (S-1) at $43.8 \%$, diploma at $25 \%$ and secondary school at $21.9 \%$ and master (S-2) at $8.3 \%$ and others only at $1 \%$. Thirdly, out of 96 women entrepreneurs, almost all of them were married (85.4\%), unmarried (6.3\%), and single mothers (8.3\%). Further, the types of businesses in which they are fully engaged are wet and dry cakes $(45.8 \%)$ and food (32.3\%). The other characteristics is that most of women culinary entrepreneurs (67.7\%) do not have employees. They run their business by themselves without the help from other people/employees. The number of women culinary entrepreneurs who have 1-4 employees is at $29.2 \%$. The source of their capital is mostly from personal fund $(66.7 \%)$ and family fund (30.2\%). Finally, the way they run their business is on an online basis $(59.4 \%)$, that is through social media and websites. Others (26\%) use an offline method by opening a stall/shop, and a small number of them (14.6\%) cooperate with other shops /people.

\section{Instrument Development}

Information needs of women culinary entrepreneurs are divided into five categories, including product, product development, training, marketing, and financial information. Five categories of the types of information questioned in this research are product information which consists of eight statements, including the type of raw materials, availability of raw materials, the nearest market to buy raw materials, variation of recipe, taste, shape, and packaging as well as brand information. Financial information comprises six statements, including the selling prices of product, cost of product delivery, prices of raw materials, prices of other business products, cost of packaging, and fees for obtaining a business permit from the related agency. The category of marketing consists of five statements, including the nearest market, product trends, availability of transportation, availability of partners or resellers and types of transportation for delivery. Product development consists of three statements, including material composition, regulation and brand attractiveness, packaging, and appearance. The last category is training related to the needs of information on training in product development, finance, promotion, business management, and self-development.

The content of the questionnaire has been thoroughly validated by researchers. Statements (items) of each category were reviewed in terms of clarity, accuracy, and relevance to evaluate the information strongly needed by women culinary entrepreneurs. At the subsequent step, the reliability of the items was tested resulting in a very high internal consistency.

\section{Data Collection and Analysis}

Data were collected through a survey by adopting a questionnaire distributed on an online basis to the community of women culinary entrepreneurs in Depok Municipality. Further, the 
data were analyzed through a software of SPSS 21 by using a table of frequency distribution to know which information needs they deem important.

\section{RESULTS}

The findings of this research were identified as the types of information considered important for women entrepreneurs in Depok Municipality, Indonesia-the types of information they need in the process of running their culinary business. According to the women culinary entrepreneurs in Depok Municipality, the types of information could make their business successful. In this section, the types of information were presented in two categories, including 'between categories' and 'within categories'. The 'between categories' information is intended to know the level of importance among five types of information. The 'within categories' information is aimed at seeing the level of importance of sub-types of information within one type of information. It should be noted that any conclusion drawn from these findings must be interpreted carefully as the data were collected at one point of time in Depok Municipality. In addition, a large number of women culinary entrepreneurs scattered across 93 cities in 34 provinces in Indonesia were not involved in this study. Therefore, these research findings can not be generalized, but they can be transferred to other cities with the same or similar settings in accordance with the nature of this research.

\section{Between Categories}

Five types of information in Table 1 below illustrate the level of importance of the types of information for women culinary entrepreneurs in the process of running their culinary business.

Table 1. Levels of Information Needs

\begin{tabular}{lccc}
\hline Types of Information & Low & Moderate & High \\
\hline Product & $0 \%$ & $13.5 \%$ & $86.5 \%$ \\
Training & $1.0 \%$ & $12.5 \%$ & $86.5 \%$ \\
Marketing & $0 \%$ & $18.8 \%$ & $81.2 \%$ \\
Finance & $1.0 \%$ & $18.8 \%$ & $80.2 \%$ \\
Product Development & $3.1 \%$ & $19.8 \%$ & $77.1 \%$ \\
\hline
\end{tabular}

Most of women culinary entrepreneurs found that the type of information including product, training, marketing, finance, and product development as illustrated in Table 1 was the type of important information required to make their culinary business successful. Most of them were convinced that information on 'product and training' (86.5\%), 'marketing' (81.2\%), 'finance' $(80.2 \%)$, 'product development' $(77.1 \%)$ was the type of important information needed by women culinary entrepreneurs in Depok Municipality to run their culinary business.

\section{Within Categories}

\section{Product Information Needs}

Table 2 below describes the result of the needs of information on product. Most of culinary entrepreneurs in Depok Municipality need information related to 'types of raw/basic materials' (67.7\%), 'availability of raw materials in the market' (68.8\%), 'the nearest market to purchase raw materials/basic materials '(57.3\%), 'variation of taste' (56.3\%) and 'variation of recipe' (53.1\%). Though almost all of this information was considered strongly important by 
these entrepreneurs, information on 'brand needs' was deemed fairly important by women culinary entrepreneurs reaching $19.8 \%$.

Table 2. Product Information Needs

\begin{tabular}{|c|c|c|c|c|c|c|}
\hline No & Information Needs & $\begin{array}{l}\text { Strongly not } \\
\text { important } \\
(\%)\end{array}$ & $\begin{array}{c}\text { Not } \\
\text { important } \\
(\%)\end{array}$ & $\begin{array}{c}\text { Fairly } \\
\text { imporatnt } \\
(\%)\end{array}$ & $\begin{array}{c}\text { Important } \\
(\%)\end{array}$ & $\begin{array}{c}\text { Strongly } \\
\text { important } \\
(\%)\end{array}$ \\
\hline 1 & $\begin{array}{l}\text { Types of raw/basic } \\
\text { materials }\end{array}$ & 1 & 0 & 6.3 & 25 & 67.7 \\
\hline 2. & $\begin{array}{l}\text { Availability of raw } \\
\text { materials in the } \\
\text { market }\end{array}$ & 0 & 0 & 3.1 & 28.1 & 68.8 \\
\hline 3. & $\begin{array}{l}\text { Nearest market to } \\
\text { purchase raw/basic } \\
\text { materials }\end{array}$ & 0 & 1 & 6.3 & 35.4 & 57.3 \\
\hline 4. & Variation of recipe & 0 & 3.1 & 11.5 & 32.3 & 53.1 \\
\hline 5. & Variation of taste & 0 & 1 & 12.5 & 30.2 & 56.3 \\
\hline 6. & Variation of shape & 0 & 2.1 & 17.7 & 35.4 & 44.8 \\
\hline 7. & $\begin{array}{l}\text { Variation of } \\
\text { package }\end{array}$ & 0 & 5.2 & 8.3 & 43.8 & 42.7 \\
\hline 8. & Brand needs & 0 & 7.3 & 19.8 & 37.5 & 35.4 \\
\hline
\end{tabular}

\section{Training Information Needs}

Table 3 indicates the result of the type of information needed by women entrepreneurs on training. All information asked to them was considered as an information need which was strongly important to them. This means that women culinary entrepreneurs want to increase their business and to have "better skills" in running their culinary business. Nevertheless, $16.7 \%$ of them considered information on financial training as fairly important.

Table 3. Training Information Needs

\begin{tabular}{llccccc}
\hline No & Information Needs & $\begin{array}{c}\text { Strongly not } \\
\text { important } \\
(\%)\end{array}$ & $\begin{array}{c}\text { Not } \\
\text { important } \\
(\%)\end{array}$ & $\begin{array}{c}\text { Fairly } \\
\text { important } \\
(\%)\end{array}$ & $\begin{array}{c}\text { Important } \\
(\%)\end{array}$ & $\begin{array}{c}\text { Strongly } \\
\text { important } \\
(\%)\end{array}$ \\
\hline 1. & $\begin{array}{l}\text { Product } \\
\text { development }\end{array}$ & 0 & 2.1 & 5.2 & 42.7 & 50.0 \\
& training & & & & \\
2. & Financial training & 0 & 1 & 16.7 & 37.5 & 44.8 \\
3. & $\begin{array}{l}\text { Promotion training } \\
\text { Business }\end{array}$ & 0 & 3.1 & 4.2 & 37.5 & 55.2 \\
& $\begin{array}{l}\text { management } \\
\text { training } \\
\text { Self-development }\end{array}$ & 0 & 2.1 & 5.2 & 43.8 & 49.0 \\
training & 1 & 6.3 & & & \\
\hline
\end{tabular}

\section{Markerting Information Needs}

Table 4 illustrates the needs of information on 'marketing'. The women culinary entrepreneurs in Depok Municipality strongly need information on the 'availability of transportation' (51\%) followed by 'types of transportation to deliver products' (44.8\%). This result indicates that most of them deliver their business products to consumers. As they run their businesses on an online basis, information related to the 'nearest market to sell products' was not considered too important. 
Table 4. Marketing Information Needs

\begin{tabular}{llccccc}
\hline No & Information Needs & $\begin{array}{c}\text { Strongly not } \\
\text { important } \\
(\%)\end{array}$ & $\begin{array}{c}\text { Not } \\
\text { important } \\
(\%)\end{array}$ & $\begin{array}{c}\text { Fairly } \\
\text { important } \\
(\%)\end{array}$ & $\begin{array}{c}\text { Important } \\
(\%)\end{array}$ & $\begin{array}{c}\text { Strongly } \\
\text { important } \\
(\%)\end{array}$ \\
\hline 1. & $\begin{array}{l}\text { Nearest market to } \\
\text { sell products }\end{array}$ & 3.1 & 1 & 17.7 & 62.5 & 15.6 \\
2 & 1 & 4.2 & 15.6 & 49 & 30.2 \\
$\begin{array}{l}\text { Interest in types of } \\
\text { products (product } \\
\text { trends) }\end{array}$ & 1 & 2.1 & 8.3 & 37.5 & 5.0 \\
3. & $\begin{array}{l}\text { Availability of } \\
\text { transportation }\end{array}$ & 0 & 7.3 & 20.8 & 41.7 & 30.2 \\
4. $\begin{array}{l}\text { Availability of } \\
\text { partners/resellers } \\
\text { Types of }\end{array}$ & 1 & 1 & 11.5 & 41.7 & 44.8 \\
transportation to \\
develiver products
\end{tabular}

\section{Financial Information Needs}

The needs of financial information were also identified in this research. Table 5 illustrates that most of women culinary entrepreneurs in Depok Municipality need information related to the 'prices of raw/basic materials' (58.3\%). This finding reveals that the information should be easily obtained by entrepreneurs. Other than the 'prices of raw/basic materials', 'selling prices of products in the market' (49\%) and 'costs of delivering products to consumers' (43.8\%) were also very important information needed by them. As most of the culinary entrepreneurs are home industry entrepreneurs, they think that information on the 'arrangement of a business permit' was less important to be obtained (32.3\%). The interesting result in this research is that the women culinary entrepreneurs in Depok Municipality did not need information on 'the prices of products from other culinary entrepreneurs'.

Table 5. Financial Information Needs

\begin{tabular}{|c|c|c|c|c|c|c|}
\hline No & $\begin{array}{l}\text { Information } \\
\text { Needs }\end{array}$ & $\begin{array}{l}\text { Strongly not } \\
\text { important } \\
(\%)\end{array}$ & $\begin{array}{c}\text { Not } \\
\text { important } \\
(\%)\end{array}$ & $\begin{array}{c}\text { Fairly } \\
\text { important } \\
(\%)\end{array}$ & $\begin{array}{c}\text { Important } \\
(\%)\end{array}$ & $\begin{array}{c}\text { Strongly } \\
\text { important } \\
(\%)\end{array}$ \\
\hline 1 & $\begin{array}{l}\text { Selling prices of } \\
\text { products in the } \\
\text { market }\end{array}$ & 0 & 4.2 & 8.3 & 38.5 & 49.0 \\
\hline 2. & $\begin{array}{l}\text { Costs of delivering } \\
\text { products to } \\
\text { consumers }\end{array}$ & 0 & 1 & 12.5 & 42.7 & 43.8 \\
\hline 3. & $\begin{array}{l}\text { Prices of } \\
\text { raw/basic } \\
\text { materials }\end{array}$ & 0 & 3.1 & 6.3 & 32.3 & 58.3 \\
\hline 4. & $\begin{array}{l}\text { Prices of products } \\
\text { from other } \\
\text { culinary } \\
\text { entrepreneurs }\end{array}$ & 1 & 9.4 & 13.5 & 50 & 26.0 \\
\hline 5. & Costs of packaging & 1 & 6.3 & 12.5 & 43.8 & 36.5 \\
\hline 6. & $\begin{array}{l}\text { Fees for obtaining } \\
\text { a business permit } \\
\text { from related } \\
\text { agency }\end{array}$ & 2.1 & 9.4 & 18.8 & 37.5 & 32.3 \\
\hline
\end{tabular}




\section{Product Development Information Needs}

Table 6 illustrates the needs of information on 'product development'. Women culinary entrepreneurs in Depok Municipality strongly need information on the 'composition of materials (nutrient, hygiene, and halal' (54.2\%) followed by 'attractiveness of brand, package, appearance' (50\%) and 'regulation (halal by Indonesian Ulema Council), Ministry of Health, Ministry of Trade, arrangement of IPR, etc)' reaching $42.7 \%$. This result shows that most of women culinary entrepreneurs in Depok Municipality want their culinary busines products to have the material composition which is nutritious, hygiened and halal considering that most of their customers are Moslems.

Table 6. Product Development Information Needs

\begin{tabular}{llccccc}
\hline No & Information Needs & $\begin{array}{c}\text { Strongly not } \\
\text { important } \\
(\%)\end{array}$ & $\begin{array}{c}\text { Not } \\
\text { important } \\
(\%)\end{array}$ & $\begin{array}{c}\text { Fairly } \\
\text { important } \\
(\%)\end{array}$ & $\begin{array}{c}\text { Important } \\
(\%)\end{array}$ & $\begin{array}{c}\text { Strongly } \\
\text { important } \\
(\%)\end{array}$ \\
\hline 1. & $\begin{array}{l}\text { Material composition } \\
\text { (nutrient, hygiene }\end{array}$ & 0 & 5.2 & 10.4 & 30.2 & 54.2 \\
and halal) & 0 & 6.3 & 18.8 & 32.3 & 42.7 \\
2. & $\begin{array}{l}\text { Regulation (halal by } \\
\text { Indonesian Ulema } \\
\text { Council), Ministry of } \\
\text { Health, Ministry of } \\
\text { Trade, arrangement } \\
\text { of IPR, etc) } \\
\text { Brand attractiveness, } \\
\text { package, appearance }\end{array}$ & 1 & 5.2 & 6.3 & 37.5 & 50.0 \\
\hline
\end{tabular}

\section{DISCUSSION}

This research discusses the needs of the types of information required by women culinary entrepreneurs to run their businesses. Researchers divided the questions into five categories, including the types of information on finance, marketing, product development, and training. In conducting this research, a descriptive quantitative approach was employed using individuals as the unit of analysis. The research was conducted in 96 women culinary entrepreneurs in Depok Municipality, Indonesia. The sample was selected from women culinary entrepreneurs who have a culinary business domiciling in Depok Municipality, Indonesia.

The findings of the research conducted in the respondents mostly at the age of 40-49 years $(58 \%)$ indicates that out of eight questions put in the category of types of information, there was a statement of 'availability of raw materials' (strongly agree at 68.8\%) in the market to be strongly important in running their culinary business. This reveals that the process of making culinary products depends very much on the availability of raw materials in the market. A culinary product may not be produced if one of the materials is not available or scarce. As a result, the product sustainability can be halted.

In terms of 'financial' information by respondents who most of them have run their business for more than 5 years (31\%) and capitalized their business independently (64\%), the statement of the 'prices of raw/basic materials' received a response of 'strongly agree' of $58 \%$. This shows that the prices of raw/basic materials is the main factor in making culinary products. If the price increase is uncertain, it can be ensured that the selling prices of the products will be increased. This will certainly influence the buying interest and trust of the consumers who are sensitive to the price of a product. Related to capital, it is not a major 
problem for women culinary entrepreneurs in Depok Municipality as their business is still a small scale one and the capital can still be fulfilled personally.

In terms of the needs of information on 'marketing', with the majority of respondents running their culinary business on an online basis (57\%), the statement of 'the nearest market to sell products' was their main concern with an 'agree' response of $62.5 \%$. This confirms that a high number of culinary women entrepreneurs undertake their activities at home. Consequently, due to their limited access to going outside their home, they seek consumers by promoting their culinary products through their social media instruments. In general, online marketing is profitable for product and brand development, though the quantity of the products sold has not certainly been as wide as the reach of its social media. This is also due to the limited reach of the buyers.

Information within the category of 'product development' with the statement of 'material composition (nutrition, hygiene, and halal) ' received a response of 'strongly agree' of 54.2\%. This is in accordance with the demand and improvement of knowledge from consumers to find out the composition of food they consume. It is not exaggerated as there are now a lot of haram (not permitted by Islamic law) food circulated freely in the market. As a result, it is natural for consumers to clarify the entrepreneurs about the food they produced. Further, in terms of the 'regulation on business permit', it is also the type of information needed by women culinary entrepreneurs in Depok Municipality with a response of 'strongly agree' at $42.7 \%$, particularly related to the 'process of obtaining a business permit' and 'place of obtaining it'

Finally, information on the training with the statement of 'promotion training' received a response of 'strongly agree' at 55.2\%. Though most of the women culinary entrepreneurs in Depok Municipality run their business from home on an online basis and most of them have finished their undergraduate study (42\%), they still need information on the 'promotion process'. It should also be noted that not many women are able to operate digital features to promote their products. Consequently, what they do is only to take pictures of their products and to upload them on social media. In fact, if they are provided with training in using digital features to promote their products, they can promote their products optimally and effectively which can also beneficial to their culinary business.

The results of the research above show that women culinary entrepreneurs in Depok Municipality are in need of various types of information related to culinary business, prior to starting a business and/or when running their culinary business. It is in line with the results of previous studies as conducted by Tamba \& Sarma (2007) on farmers who found that the developed and developing farmers equally needed various types of information on agriculture, such as information on increasing production and quality of vegetables, availability of production facilities and capital, location of marketing and vegetable prices, technology for processing vegetable products, and methods of analyzing vegetable farming business. In addition, the results of this research confirm the results of previous research conducted by Nelson (1987), Kassim (2010), Saleh \& Lasisi (2011), Parvez (2012), Kassim, et.al. (2014), Chaudhary (2015), Kassim, et.al. (2016), and Yohana (2016) that entrepreneurs need various types of information to run their business.

\section{CONCLUSION AND SUGGESTIONS}

Based on the data processing tested quantitatively descriptively, a conclusion can be drawn that the type of information on 'product', 'finance', 'marketing', 'product development', and 'training' and their derivatives is the type of information that is strongly needed and very 
important for women culinary entrepreneurs in Depok Municipality in the process of running their culinary business.

Information on the 'product' that is strongly needed consists of eight statements, including 'type of raw materials', 'availability of raw materials', 'nearest market to purchase raw materials', 'variation of recipe', 'taste', 'shape and packaging' and information on 'brand' which ranked first. In addition, information on training comprising the training of 'product development, 'finance', 'promotion', 'business management', and 'self-development' occupied the same position with the information on the product.

The third category was occupied by the needs of 'information on marketing' including information related to the 'nearest market', 'product trends', 'availability of transportation', 'availability of partners/resellers', and type of transportation for delivering products. Subsequently, 'financial' information which consists of six statements, including 'selling prices of product',' costs of delivering products', 'prices of raw materials', 'prices of other business products', 'costs of packaging', and 'fees for obtaining a business permit from the related agencies' ranked fourth as the type of information strongly needed by women culinary entrepreneurs in Depok Municipality. The last information strongly needed by women culinary entrepreneurs is the information related to 'product development' with three statements, including 'material composition', 'regulation', and 'brand attractiveness, packaging, and appearance'.

This research deals with two limitations. First, the data of the research were taken from Depok Municipality in Indonesia, which did not fully represent women culinary entrepreneurs in all cities in Indonesia. Further research can be conducted to investigate more women culinary entrepreneurs from a wide range of cities or provinces in Indonesia to find out whether other women culinary entrepreneurs have the same opinions on the type of information strongly needed. Second, the data were collected at one point of time. Consequently, the result of this research may differ from the conditions in the future. Therefore, similar research should be conducted in the future.

\section{References}

Chaudhary, S. (2015). Information needs of rural women entrepreneurs. New Media and Mass Communication. 4448 .

DeCenzo \& Robbins. (1999). Human resource management, Sixth Edition. New York: John Wiley \& Sons, Inc.

Drucker, P. (1954). The practice of management. New York: Harper and Row Publishers.

Faibisoff, S. G., \& Ely, D. P. (1974). Information and information needs. Information Reports and Bilbiographies. Vol $5(5), 2-15$.

Kassim, N. A. (2010). Information needs of malaysian bumiputera would be entrepreneurs. Malaysian Journal of Library \& Information Science, 57-69.

Kassim, N. A., Baharuddin, K., Ariff, N. Z., \& Buyong, S. Z. (2016). Business information needs of small and mediumsized enterprise manager. International Journal of Academic Research in Business and Social Sciences. 151-160.

Kassim, N. A., Buyong, S. Z., \& Kasmarini, B. (2014). Information Needs of People with Entrepreneurial Intention. International Journal of Academic Research. 35-39.

Kotler, P. \& Keller, K. (2014) Marketing management. 15th Edition, Prentice Hall, Saddle River

Kotler, P., Armstrong, G., \& Cunningham, M. H. (2005). Principles of marketing. Toronto: Pearson Prentice Hall

Likert, R. (1967). New patterns of management. New York: McGraw-Hill

McCarthy, J. E. (1964). Basic marketing. A managerial approach. Homewood, IL: Irwin 
Murari, Durga \& Nagarkar, Shubhada. (2013). Information nequirements of women entrepreneurs in Pune Municipality. IFLA WLIC 2013 Singapore. http://library.ifla.org/169/1/189-murari-en.pdf.

Nation, I.S.P. \& Macalister, J. (2010). Language Curriculum Design. New York. Routledge.

Nelson, G.W. (1987). Information Needs of Female Entrepreneurs. Journal of Small Business Management, P 38-44.

Parvez, A. (2012). Information Needs of Manager in India Financial Institution. Annals of Library and Information Studies. 59, 64-73.

Rajagopal (2007). Marketing dynamics theory and practice. New Delhi: New Age International.

Saleh, A. G. \& Lasisi, F. I. (2011). Information needs and information seeking behavior of rural women in Borneo State, Nigeria. Library of Philosophy and Practice (ejournal), 2-2011.

Tamba, M., \& Sarma, M. (2007). Faktor-faktor yang mempengaruhi kebutuhan informasi pertanian bagi petani sayuran di Provinsi Jawa Barat. Jurnal Penyuluhan. 24-34.

Yamit, Z. (2003). Manajemen produksi dan operasi. Second edition. Ekonosia Fakultas Ekonomi UII, Yogyakarta.

Yates, B. (1984). Information needs of human beings. International Forum on Information Documentation 9, (1), 23-28.

Yohana, Corry. (2016). Pelatihan motivasi kewirausahaan dan menganalisis peluang usaha, membuat rencana bisnis bagi tenaga kerja wanita (TKW) Purna di Desa Cibalong Kecamatan Gunung Guruh, Sukabumi. Jurnal Sarwahita, 13 (2).

Yusuf, T. I. (2012). Informastion Needs and Information Seeking Behaviour of Women Artisan Inoffa Metropolis. Library Pshilosophy and Practice (e-Journal), 10-2012. 